\section{Journal of Energy \&. \\ Environmental Sciences}

Vol. 5, $\mathrm{N}^{\circ} 1,2021$

\title{
Growth evaluation of the microalgae Chlorella sp. with tannery effluent from the soaking stage [Evaluación del crecimiento de la microalga Chlorella $s p$. con efluente de curtiembre de la etapa de remojo]
}

\author{
Jorge Mendoza Bobadilla(iD*a, Adolfo Guerrero Escobedo (ib), Carlos Vasquez \\ Blas (iD) $b$, Astrid Alfaro Flores ${ }^{a}$, Giancarlo Flores Quiñones ${ }^{a}$
}

aLaboratorio de Investigación en Aguas, Ingeniería Ambiental, Universidad Nacional de Trujillo, Perú.

bLaboratorio de Investigación en Físicoquímica, Ingeniería Química, Universidad Nacional de Trujillo, Perú.

*jmendoza@unitru.edu.pe

Received: 04 June 2021; Accepted: 13 June 2021; Published: 28 June 2021

\section{Resumen}

En esta investigación se buscó determinar el porcentaje ideal de agua de remojo de la industria de curtiduría como fuente nutritiva para la microalga Chlorella sp.; evaluando el efecto de la concentración inicial de 15, 30, 45, 60 y $75 \%$ de agua de remojo en contacto con las microalgas en una primera fase y una nueva evaluación con 30, 45 y $60 \%$ de agua de remojo utilizando la microalga adaptada de la primera fase en la segunda. La densidad celular a lo largo del tiempo se determinó por conteo celular en una cámara de neubauer hasta llegar a la fase estacionaria en todas las muestras. Los resultados evidencian que, las microalgas adaptadas al efluente utilizado presentan una cinética de crecimiento más similar a la de microalgas cultivadas en un medio convencional. Del mismo modo se determinó que con una concentración del $30 \%$ de agua de remojo se obtuvo un mejor crecimiento celular. Se concluye que la utilización del agua de remojo es una forma eficiente de cultivar microalgas, contribuyendo así a disminuir la contaminación por efluentes de curtiduría.

Palabras clave: Agua de remojo, microalgas, Chlorella sp

\begin{abstract}
This research sought to determine the ideal percentage of soaking water from the tannery industry as a nutrient source for the microalgae Chlorella $s p$.; evaluating the effect of the initial concentration of $15,30,45,60$ and $75 \%$ of soaking water in contact with the microalgae in a first phase and a new evaluation with 30,45 and $60 \%$ of soaking water using the adapted microalgae from the first phase into the second. Cell density over time was determined by cell counting in a neubauer chamber until reaching the stationary phase in all samples. The results show that the microalgae adapted to the effluent used present growth kinetics more similar to that of microalgae grown in a conventional medium. In the same way, it was determined that a better cell growth was obtained with a $30 \%$ concentration of soaking water. It is concluded that the use of soaking water is an efficient way to cultivate microalgae, thus helping to reduce pollution from tannery effluents.
\end{abstract}

Keywords: Soaking water, microalgae, Chlorella sp.

\section{Introduction}

The leather tanning industry is not only one of the industries that requires the most water for its production process, it is also one of those that has the most polluting effluents due to the presence of sulfides, its high organic and inorganic load, as well as the large amount of suspended matter, colorants, the high content of chromium and other metals. (Chowdhury et al, 2015). 


\section{Journal of Energy \&. Environmental Sciences}

Vol. 5, $\mathrm{N}^{\circ} 1,2021$ EES
Copyright $\odot 2021$, CINCADER.

ISSN 2523-0905

DOI: https://doi.org/10.32829/eesj.v5i1.129
A publication of CINCADER

Centre of Research and Training for Regional Development Online at www.journals.cincader.org

It is calculated that to process $1 \mathrm{Kg}$ of skin, between 25 and $80 \mathrm{~L}$ of water are required (Swartz et al., 2017), with the soaking stage representing around $50-55 \%$ of the total load of pollutants discharged by it. industry (Chowdhury et al., 2015), having as typical components salt, manure, blood, dirt, globular skin proteins, biocides, surfactants and degreasers. (Swartz et al., 2017).

The need to treat these effluents is essential not only to protect the bodies of water or the sewers to which they are discharged, but also to prevent risks to human health. The search for treatments that provide alternative economic and ecological means, positioned biotechnology as an increasingly viable option, being the studies that use microorganisms such as microalgae, bacteria, fungi and their by-products, the most promising. (Pena et al., 2019).

Microalgae are photosynthetic organisms that have the ability to grow under autotrophic, heterotrophic and mixotrophic conditions, the latter includes wastewater and manure as sources of organic substances. The biomass that is generated thanks to its adaptability to a great diversity of ecosystems and biotechnological processes, can be used in or for the production of food, concentrates, active compounds, biofuels, biofertilizers and bioremediation. (Ortiz et al., 2012).

Although studies on the performance and effectiveness of microalgae in the treatment of domestic and industrial effluents are abundant, the potential use of many effluents as alternative cultivation mediums for microalgae is not fully explored yet, which would mean not only the reduction of the discharge of these effluents without treatment to any body of water or to the sewer system, but rather a reduction in the cost of producing microalgal biomass due to the replacement of the conventional nutrient source. For this reason, the objective of this work is to evaluate the growth of the microalgae Chlorella sp. using tannery effluent from the soaking stage as a replacement for the conventional nutrient.

\section{Materials and Methods}

The microalgae used in this research were obtained from the Water Research Laboratory (LIA) of the National University of Trujillo (UNT). The culture medium used for its cultivation was a commercial fertilizer called "Hydroponic Solution", which was acquired from the Universidad Nacional Agraria La Molina.

The effluent used in this study was provided by the Ecologicas del Norte tannery in the city of Trujillo.

\subsection{Effluent preparation}

The soaking water used in both the first and second treatment was used the same day it was produced. To carry out the pretreatment, it was allowed to settle for approximately 1 hour, then part of the supernatant was taken that was filtered through a strainer and subsequently sterilized in the autoclave at $120^{\circ} \mathrm{C}$ for 30 minutes to eliminate microorganisms that were present in the effluent and that could interfere in the consumption of nutrients by microalgae. Finally, it was allowed to cool to room temperature in a hermetically sealed bottle for 2 hours, to start the experiments.

\subsection{Development of the experiments}

The experiments were carried out in small bioreactors flasks of $500 \mathrm{ml}$ capacity at room temperature, with day and night photoperiods of 12 hours each, with constant agitation through aeration pumps, which were connected to a solution of sulfate of $10 \%$ copper to sterilize the air entering the reactors and humidify it, later the air was standardized in a home homogenizer and finally it was directed to the $500 \mathrm{ml}$ bioreactors, with $400 \mathrm{~mL}$ being the final volume to be used. The treatments were carried out at $15,30,45,60$ and $75 \%$ by volume of tannery soaking effluent and the difference in microalgal solution, later in a second phase, the microalgae solutions that were in contact with 30,45 and $60 \%$ of the soaking effluent as they exhibited the best performance 


\section{Journal of Energy \&. Environmental Sciences}

Vol. 5, $\mathrm{N}^{\circ}$ 1, 2021

Copyright @ 2021, CINCADER.

ISSN 2523-0905

DOI: https://doi.org/10.32829/eesj.v5i1.129

when in contact with the effluent. These were placed in bioreactors of $1 \mathrm{~L}$ each with an effective volume of $750 \mathrm{ml}$, the conventional nutrient used was added and allowed to aerate for 5 more days to later put them back in contact with the effluent concentrations to which they were exposed. All tests were carried out in triplicate.

\subsection{Cell density analysis}

The cell concentration was determined in all the treatments by cell counting under a microscope every two days until reaching the stationary phase of all the samples, using a neubauer chamber. The calculation of the cell concentration was carried out using the following equation:

Where:

$$
C=N .10^{4} . d i l
$$

$C=n^{\circ}$ cells $/ m L$

$\mathrm{N}=$ Average number of cells in counted quadrants

dil $=$ dilution factor

\section{Results}

3.1. Evaluation of the effect of the concentration of soaking water on the growth of Chlorella sp.

In figure 1, the growth results of the Chlorella $s p$ microalgae are shown by evaluating its cell density in different concentrations of soaking water, all of them compared to the growth curve of a control reactor without exposure to effluent.

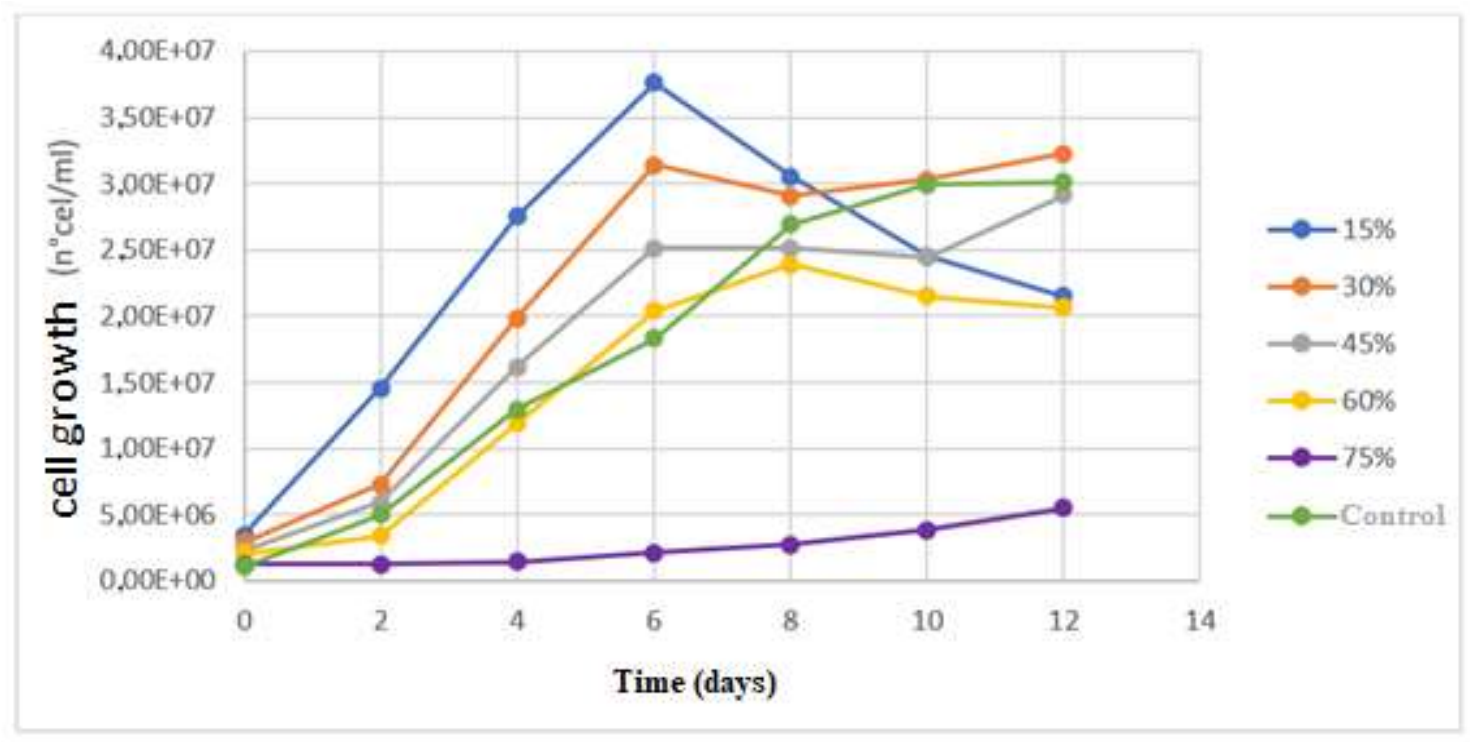

Figure 1. Growth curves of the microalgae Chlorella sp. using different concentrations of soak water from the tannery industry and a conventional nutrient.

The pretreated soaking water used in the experiments showed that it is a source of nutrients for the microalgae Chlorella sp., Exceeding in certain concentrations the conventional nutrient used in the cultivation of this microalgae, these concentrations were 15 and $30 \%$, as shown observed in figure 1. It has been reported in a similar study that, with concentrations of 10,25 and $50 \%$ of 


\section{Journal of Energy \&. Environmental Sciences}

Vol. 5, $\mathrm{N}^{\circ}$ 1, 2021

tannery effluent, the cellular growth of the microalgae Scenedesmus $\mathrm{sp}$. It is quite similar to the one presented with your traditional growing medium (Ajayan et al, 2015).

The effluents from Tannery Soak show high turbidity, see photo 1; whose suspended particles scatter light reducing the photosynthetic activity of algae; evidenced by using $75 \%$ soaking water which inhibits the growth of the microalgae Chlorella $s p$ as seen in Figure 1. This has been described by Ajayan, K. et al., (2015), where when using concentrations above $50 \%$ of tannery effluent with Scenedesmus sp. microalgae, inhibits its growth and biomass production.

The efficiency of the cultivation of microalgae with tannery soaking effluent is due to the fact that they present high amounts of carbon (which can be verified by presenting a high BOD), nitrogen in the form of nitrates and ammonium $\left(\mathrm{NO}^{3-}, \mathrm{NH}_{4}{ }^{+}\right)$and phosphorus as phosphates $\left(\mathrm{PO}_{4}^{3-}\right)$ (Rosales et al., 2018.), which are the main macronutrients necessary to regulate lipid content, nucleic acid formation, energy transfer and for biomass production. (Hernández and Labbé, 2014).

Although it is true, the highest biomass production is obtained with the sample at $15 \%$ of the soaking effluent, but on the eighth day the microalgae acquired a slightly yellow color, showing depletion of nutrients, while in the sample at $30 \%$ of effluent, the growth It remained stable, evidenced by observing the microscope, as well as the green color of the solution, see photo 2 .

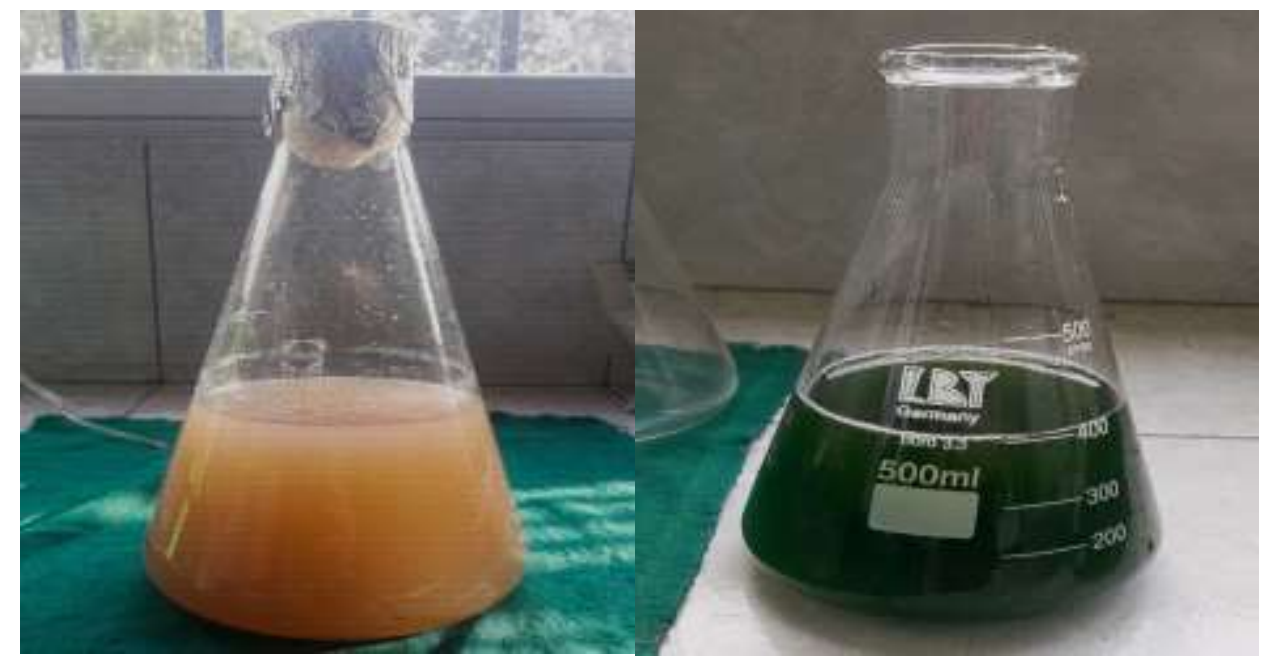

Photo 1: Left, tannery soak effluent sterilize in the autoclave at $120^{\circ} \mathrm{C}$ for 30 minutes. Photo 2: Right, shows $30 \%$ of Soak Effluent on the eighth day of treatment.

\subsection{Evaluation of the effect of the concentration of soaking water on the growth of Chlorella sp. adapted}

Figure 2 shows the growth curves of the microalgae adapted to the effluent. Compared to figure 1 , it has a slightly higher cell density, reaching with $30 \%$ of soaking water at its maximum growth point in the exponential phase up to $4.0 \times 10^{7}$ cells $/ \mathrm{mL}$, with $45 \%$ up to $3,1 \times 10^{7}$ cells $/ \mathrm{mL}$ and with $60 \%$ up to $2.7 \times 10^{7}$ cells $/ \mathrm{mL}$. 


\section{Journal of Energy \&. Environmental Sciences}

Vol. 5, $\mathrm{N}^{\circ}$ 1, 2021

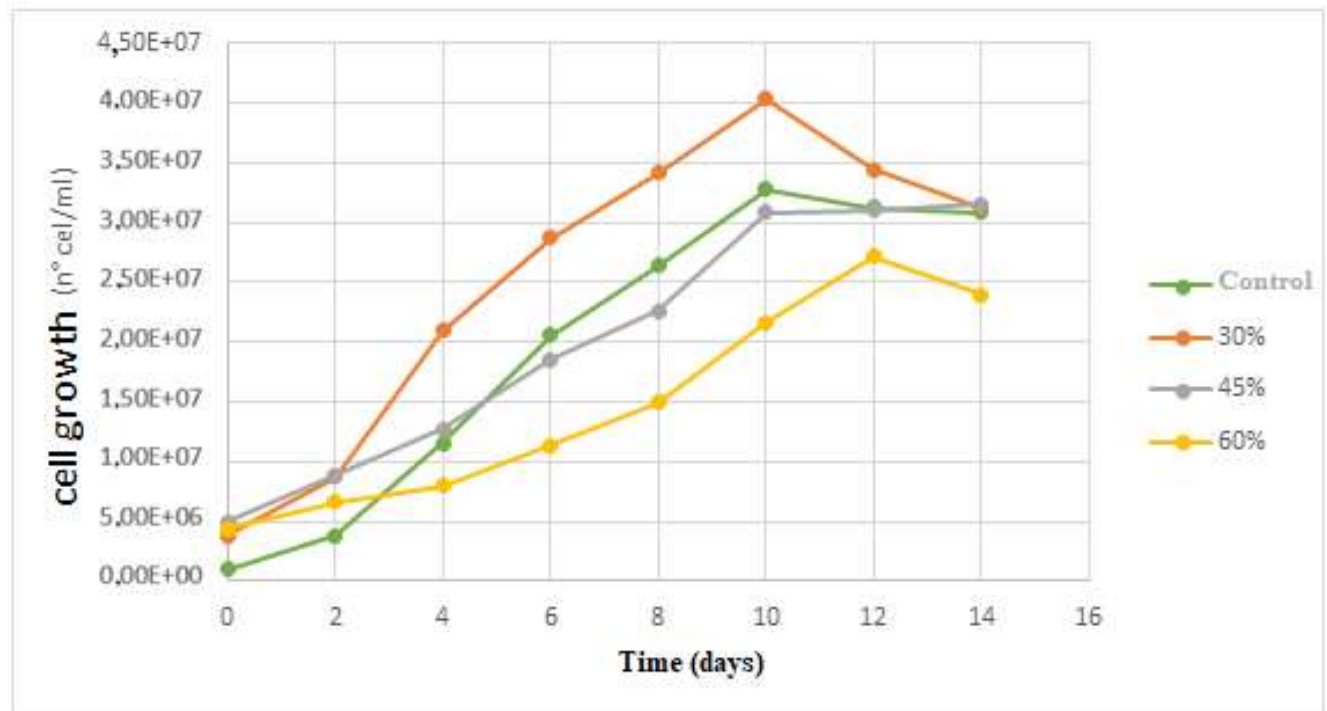

Figure 2. Growth curves of the microalgae Chlorella sp. adapted to various concentrations of soak water from the tannery industry compared to microalgae using a conventional nutrient

Likewise, in Figure 2, it is observed that the growth kinetics is very similar to the microalgae cultivated with the conventional nutrient "Hydroponic Solution", and that they have not been in contact with any effluent. This kinetics is similar to that presented by Chankhong et al. (2018), in which the stationary phase of the microalgae Chlorella $s p$. It starts on the tenth day of culture, as can be seen in each of the treatments carried out as well as in the control bioreactor.

In the research carried out by Ajayan et al., (2015), when using a $75 \%$ concentration of tannery effluent for the treatments, it is observed that the stationary phase of the microalgae shortens and begins on day 6 , but when they use concentrations below $50 \%$, the curves show the onset of the stationary phase on day 8 and 10, as is also indicated by the growth curves in the present study, which, when performing the treatments with adapted microalgae, the stationary phase no longer it begins on day 6 as seen in Figure 1, if not it begins on day 10 and 12 of treatment.

\subsection{Statistic analysis}

Table 1 breaks down the cell growth variability into contributions due to various factors. Since the Type III sum of squares has been chosen (the default), the contribution of each factor is measured by eliminating the effects of the other factors. The P-values test the statistical significance of each of the factors. Since $2 \mathrm{P}$-values are less than 0.05 , these factors have a statistically significant effect on cell growth with a $95.0 \%$ confidence level.

Table 1. Analysis of Variance for the cell growth of the microalgae Chlorella $s p$. with tannery effluent from the soaking stage

\begin{tabular}{llllll}
\hline \multicolumn{1}{c}{ Source } & Sum of squares & LG & Middle square & Reason- $F$ & Value- $P$ \\
\hline MAIN EFFECTS & & & & & \\
A:Soak water percentage & $3,7530 \times 10^{15}$ & 4 & $9,3825 \times 10^{15}$ & 26,95 & 0,0000 \\
B:Time & $4,2753 \times 10^{15}$ & 6 & $7,1255 \times 10^{14}$ & 20,47 & 0,0000 \\
RESIDUES & $2,0538 \times 10^{15}$ & 59 & $3,4810 \times 10^{13}$ & & \\
\hline TOTAL (CORRECTED) & $1,0082 \times 10^{16}$ & 69 & & & \\
\hline
\end{tabular}




\section{Journal of Energy \&. Environmental Sciences}

Vol. 5, $\mathrm{N}^{\circ} 1,2021$

Copyright @ 2021, CINCADER.

ISSN 2523-0905

DOI: https://doi.org/10.32829/eesj.v5i1.129

Figure 3 shows a comparison between an average of the cell growth values of the Chlorella sp microalgae using 5 concentrations of soaking water $(15,30,45,60$ and $75 \%$ of the effective volume of the bioreactor), regardless of the treatment time. In this figure it is observed that the best results in this first phase of the study are exhibited using 15 and $30 \%$ soaking water.

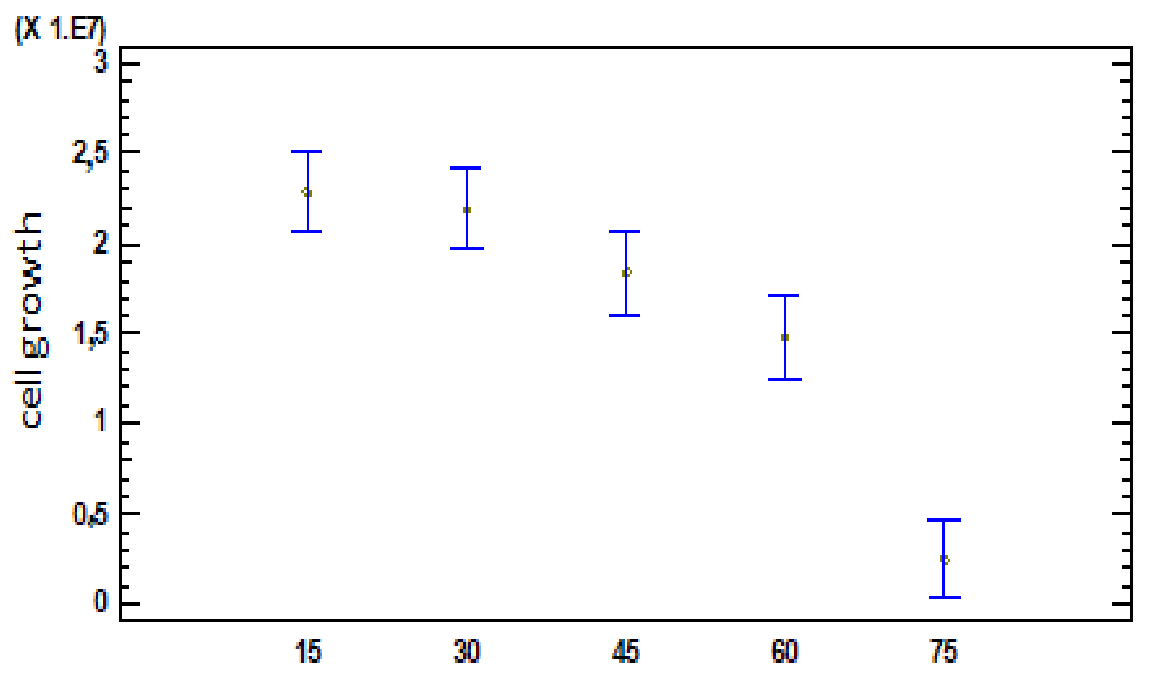

Percentage of soaking water

Figure 3. Comparison between cell growth means of microalgae exposed to 15, 30, 45, 60 and $75 \%$ of soaking water

Table 2 shows the variability of Cell Growth in contributions due to various factors. Since 2 Pvalues are less than 0.05 , both the percentage of soak water and the time have a statistically significant effect on Cell Growth with a $95.0 \%$ confidence level.

Table 2. Analysis of Variance for the cell growth of the microalgae Chlorella sp. adapted with tannery effluent from the soaking stage

\begin{tabular}{llllll}
\hline \multicolumn{1}{c}{ Source } & Sum of squares & $L G$ & Middle square & Reason- $F$ & Value- $P$ \\
\hline MAIN EFFECTS & & & & & \\
A:Soak water percentage & $8,8846 \times 10^{14}$ & 2 & $4,4423 \times 10^{14}$ & 28,73 & 0,0000 \\
B:Time & $4,5307 \times 10^{15}$ & 7 & $6,4725 \times 10^{14}$ & 41,86 & 0,0000 \\
RESIDUES & $5,8760 \times 10^{14}$ & 38 & $1,5463 \times 10^{13}$ & & \\
\hline TOTAL (CORRECTED) & $6,0068 \times 10^{15}$ & 47 & & & \\
\hline
\end{tabular}

Figure 4 shows a comparison between an average of the cell growth values of the Chlorella $s p$ microalgae using 3 concentrations of soaking water (30, 45 and $60 \%$ of the effective volume of the bioreactor), regardless of the treatment time. In this figure it is observed that the best results in this first phase of the study are exhibited using $30 \%$ of soaking water in the effective volume of the bioreactor. 


\section{Journal of Energy \&. Environmental Sciences}

Vol. 5, $\mathrm{N}^{\circ}$ 1, 2021

Copyright (C) 2021, CINCADER.

ISSN 2523-0905

DOI: https://doi.org/10.32829/eesj.v5i1.129

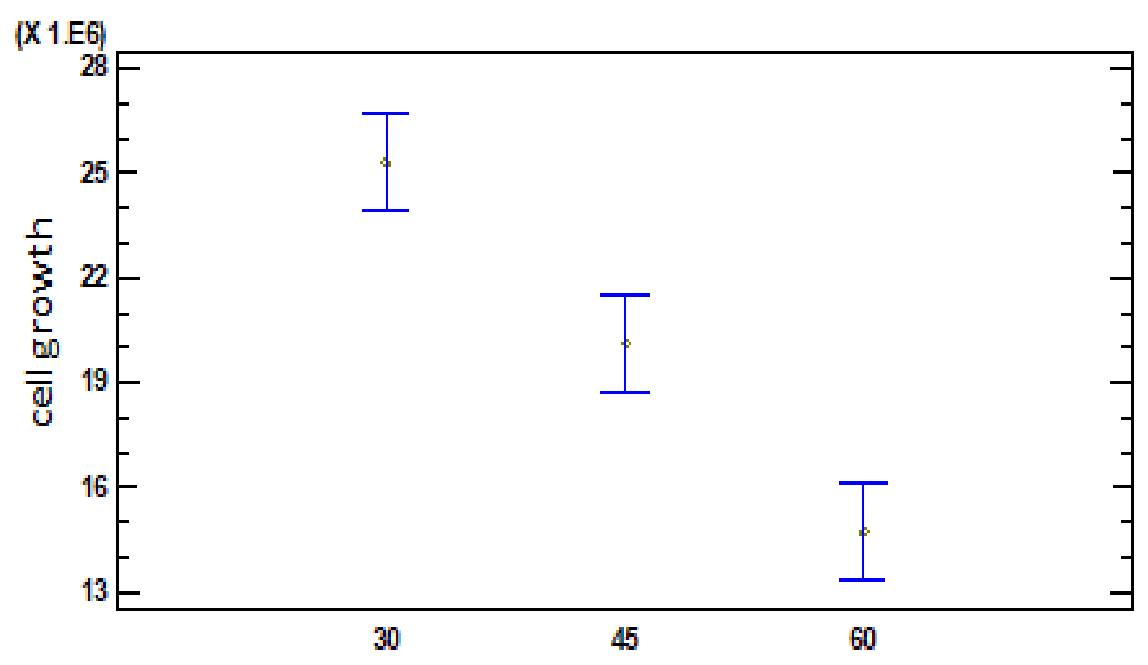

Percentage of soaking water

Figure 4. Comparison between cell growth means of adapted microalgae exposed to $30,45,60 \%$ of soaking water.

\section{Conclusions}

The tannery soaking water can be efficiently used as a nutrient for the cultivation of microalgae, while, using the effluent for this purpose, its discharge into the sewer and its possible contribution to water pollution and impact on human health.

The concentration of soaking water influences the optimization of the growth of the microalgae Chlorella sp. being the best concentration to use $30 \%$ of the effective volume of the reactor in which the culture was carried out, either working with microalgae in its first contact stage or those that are adapted to the affluent.

\section{Acknowledgments}

The authors wish to thank the Water Research Laboratory and the Clean and / or Emerging Technologies Laboratory of the School of Environmental Engineering of the National University of Trujillo for facilitating access to their environments and their equipment for the development of this research. 


\section{Journal of Energy \&. Environmental Sciences}

Vol. 5, $\mathrm{N}^{\circ}$ 1, 2021

Copyright @ 2021 , CINCADER.

ISSN 2523-0905

DOI: https://doi.org/10.32829/eesj.v5i1.129

\section{CINCADER}

Centre of Research and Training for

Regional Development

Online at www.journals.cincader.org

\section{References}

Ajayan Kayil Veedu, Muthusamy Selvaraju, Pachikaran Unnikannan \& Palliyath Sruthi. (2015). Phycoremediation of tannery waste water using microalgae Scenedesmus species. International Journal of Phytoremediation, 17(10), 907-916. DOI: $10.1080 / 15226514.2014 .989313$

Chankhong, K., Chotigeat, W. \& lewkittayakorn, J. (2018). Effects of culture medium on growth kinetics and fatty acid composition of Chlorella sp. T12. Songklanakarin J. Sci. Technol, 40 (5), 1098-1104. DOI: 10.14456/sjst-psu.2018.136

Chowdhury, M., Mostafa, M. G., Biswas, T. K., Mandal, A., \& Saha, A. K. (2015). Characterization of the Effluents from Leather Processing Industries. Environmental Processes, 2(1), 173187. DOI:10.1007/s40710-015-0065-7

Hernández-Pérez, A. y Labbé, J. I. (2014). Microalgas, cultivo y beneficios. Revista de Biología Marina y Oceanografía, 49(2), 157-173. DOI 10.4067/S0718-19572014000200001

Ortiz, M., Cortés C., Sánchez, J., Padilla, J. \& Otero, A. (2012). Evaluación del crecimiento de la microalga Chlorella sorokiniana en diferentes medios de cultivo en condiciones autotróficas y mixotróficas. Orinoquia, 16(1), 11-20

Pena, A., Bertoldi, C., Fontoura, J., Trierweiler, L. \& Gutterres, M. (2019). Consortium of Microalgae for Tannery Effluent Treatment. Brazilian Archives of Biology and Technology, 62, 1-10. https://dx.doi.org/10.1590/1678-4324-2019170518

Rosales A.G., Rodríguez C.D. y Ballen-Segura M. (2018). Remoción de contaminantes y crecimiento del alga Scenedesmus sp. en aguas residuales de curtiembre, comparación entre células libres e inmovilizadas. Ingeniería y Ciencia, 14(28), 11-34. DOI:10.17230/INGCIENCIA.14.28.1

Swartz, C., Jackson-Moss, C., Rowswell, R., Mpofu, A. \& Welz, P. (2017). Water and wastewater management in the tanning and leather finishing industry: Natsurv 10 (2nd ed). Report to the Water Research Commission. DOI: 10.13140/RG.2.2.35505.02402 